and neocortex in memory. In J. H. Byrne \& W. O. Berry (Eds.), Neural models of plasticity (pp. 240-265). San Diego: Academic Press.

Rumelhart, D. E., Zipser, D. (1986). Feature discovery by competitive learning. In D. E. Rumelhart \& J. McClelland (Eds.), Parallel distributed processing: Explorations in the microstructure of cognition (pp. 151-193). Cambridge, MA: MIT Press.

SCHmajuK, N. A. (1990). Role of the hippocampus in temporal and spatial navigation: An adaptive neural network. Behavioral Brain Research, 39, 205-229.

SHARP, P. E. (1991). Computer simulation of hippocampal place cells. Psychobiology, 19, 103-115.

SharP, P. E., Kubie, J. L., * Muller, R. U. (1990). Firing properties of hippocampal neurons in visually symmetrical environments:
Contributions of multiple sensory cues and mnemonic processes. Journal of Neuroscience, 10, 3093-3105.

Tolman, E. C. (1948). Cognitive maps in rats and men. Psychological Review, 55, 189-208.

Treves, A., Rolls, E. T. (in press). Computational constraints suggest the need for two distinct input systems to the hippocampal CA3 network. Hippocampus.

ZIPSER, D. (1985). A computational model of hippocampal place fields. Behavioral Neuroscience, 99, 1006-1018.

(Manuscript received October 18, 1991; revision accepted for publication January 8, 1992.)

\title{
Jean S. Morgan 1922-1992
}

The Governing Board and the Publications Committee of the Psychonomic Society regret to announce the death of Jean S. Morgan, widow of Clifford T. Morgan, in Austin on February 3, 1992.

Jean Morgan was an integral part of the journal publications operation from its inception in 1964, and was a working member of the Publications Office at the time of her death. Her colleagues at the Publications Office are deeply saddened by this unexpected event, and join the Society's Governing Board and Publications Committee in extending their condolences to her sons, Pete and Michael, and her daughter, Pat, and their families.

For those who may wish to make a contribution in her memory, the Morgan family have suggested the American Red Cross (or Red Cross Disaster Relief Fund (Centex), c/o Hartland Bank, P.O. Box 10994, Austin, TX 78766), the organization in which Jean Morgan was an active volunteer for over 20 years. 